\title{
Evidence for Shallow Zonal Jets in the South Equatorial Current Region of the Southwest Pacific
}

\author{
DAVID J. WEBB \\ Southampton Oceanography Centre, Southampton, United Kingdom
}

(Manuscript received 20 January 1999, in final form 20 May 1999)

\begin{abstract}
At depths above $1000 \mathrm{~m}$, the currents of the southwestern Pacific are traditionally considered to be dominated by the broad westward flow of the South Equatorial Current, part of the South Pacific subtropical gyre. Results from the OCCAM global ocean model, reported here, indicate that in reality the South Equatorial Current is broken up into a series of zonal jets by the extensive shallow topography associated with islands and reefs. This paper discusses the large-scale structure of the jets and their effect on the temperature and salinity fields. It is shown that some of the jets advect cores of high or low salinity water, which may be used experimentally to identify the jets and their pathways. Comparisons with hydrographic observations show some agreement with the model results but a more detailed experimental program is required.
\end{abstract}

\section{Introduction}

This paper is concerned with numerical model results describing the structure of the South Pacific South Equatorial Current (SEC) in the region between $10^{\circ} \mathrm{S}$ and $30^{\circ} \mathrm{S}$ and between $170^{\circ} \mathrm{E}$ and the Australian continental shelf. At $20^{\circ} \mathrm{S}$, the large-scale analyses of the hydrographic measurements indicate a broad westward flow at a depth of a few hundred meters (Wyrtki 1962a,b; Tsuchiya 1981, 1982; Reid 1986, 1997). In practice there are extensive reefs and islands that block the flow and, as we shall see, the numerical model results indicate that these cause a complex set of jets and eddies. Near the Australian continental shelf the SEC splits into two branches that feed the East Australian Current to the south and the West Queensland Current to the north (Church 1987; Hughes 1993).

The numerical model data come from the Ocean Circulation and Climate Advanced Modelling project (OCCAM) $1 / 4$ degree global model. As with other high-resolution ocean models (Semtner and Chervin 1992; Stammer et al. 1996; McClean et al. 1997), it resolves the oceanic Rossby radius and so develops boundary currents, eddy fields, and frontal systems, which com-

Corresponding author address: Dr. David J. Webb, James Rennell Division, Southampton Oceanography Centre, Empress Dock, Southampton SO14 3ZH, United Kingdom.

E-mail: David.Webb@soc.soton.ac.uk pare well with observations. The high resolution also allows small scale topographic features to be represented correctly. In the Coral Sea this means that the model resolves the island chains and reef systems that are a major feature of the region.

Wyrtki $(1962 a, b)$ was one of the first to carry out a detailed study of the flow into the southwest Pacific. Using a hydrographic section that extended from New Zealand to Fiji and the Solomon Islands, he identified a series of key water masses. The first of these is the near-surface low salinity layer $\left(T>24^{\circ} \mathrm{C}, \mathrm{S}<35.6\right.$ psu) found north of $25^{\circ} \mathrm{S}$. Beneath this lies the high salinity subtropical lower water $\left(18^{\circ} \mathrm{C}<T<25^{\circ} \mathrm{C}, 35.5\right.$ $<S<36.0 \mathrm{psu}$ ), connected to the surface layer farther south. On the basis of oxygen concentrations he split the subtropical lower water into northern and southern components. The southern component has high oxygen values and is associated with the high salinity surface outcrop region north of New Zealand near $30^{\circ} \mathrm{S}, 180^{\circ} \mathrm{E}$. The northern component is found at depths near $200 \mathrm{~m}$ at $180^{\circ} \mathrm{E}$ and is assumed to come from a second high salinity surface region found in the eastern South Pacific near $20^{\circ} \mathrm{S}, 120^{\circ} \mathrm{W}$.

These areas of surface high and low salinity are clearly shown in Fig. 3b of Reid (1997). Reid also shows the band of surface low salinity that runs east-southeast from New Guinea and eventually splits the two regions of high salinity surface water referred to above. Donguy and Hénin (1975a) studied the low salinity region north of New Caledonia and argued that it must be due to 


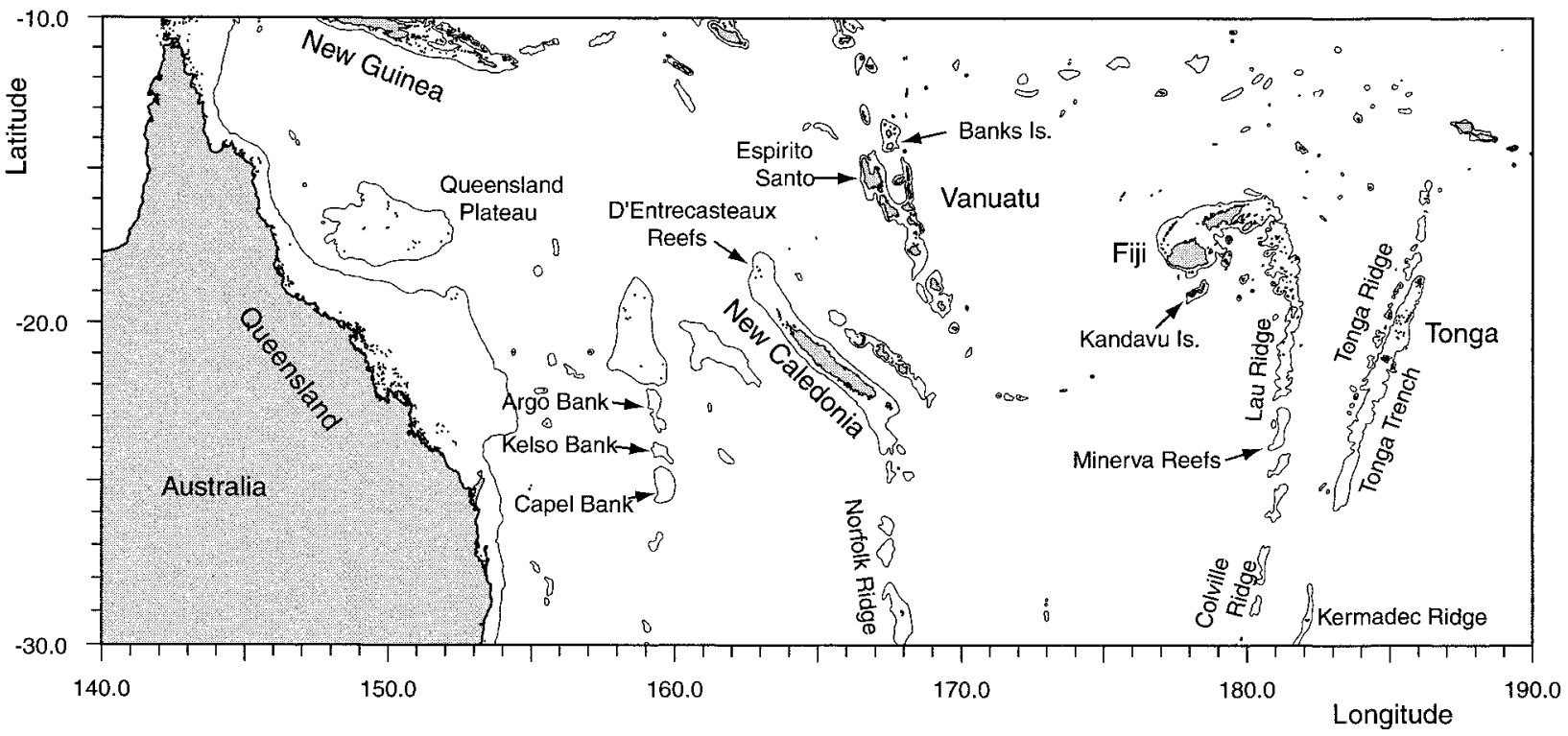

FIG. 1. The Coral Sea, with the 1000-m depth contour and features named in the text. The land outline and depth contours are from the digitized GEBCO Atlas (NERC 1997).

local rainfall. In a further study, Delcroix and Hénin (1991) showed that the minimum salinities are found a few degrees south of the main precipitation band and suggest that this is a consequence of the southward Ekman transport in the surface layer.

The analyses of Tsuchiya $(1981,1982)$ and Reid (1997) agree with and extend that of Wyrtki (1975). They show that in the region of the date line, near $20^{\circ} \mathrm{S}$, there is a broad westward flow at a few hundred meters depth associated with the South Equatorial Current. However at the surface the flow is weak and south of $20^{\circ} \mathrm{S}$, all three authors show strong eastward flows.
Reid also noted that the center of the gyre moves southward with depth. A similar behavior is seen in de Szoeke's four-layer ventilated thermocline model of the South Pacific (de Szoeke 1987). The model shows good agreement with observations between 300 and $1000 \mathrm{~m}$ but in going from level two to the surface layer, the center of the model gyre does not move far enough to the north. As a result the model shows a westward nearsurface flow between $20^{\circ} \mathrm{S}$ and $30^{\circ} \mathrm{S}$, whereas the observations referred to earlier show an eastward flow.

The picture is made more complicated by some detailed studies of the Coral Sea to the north and west of

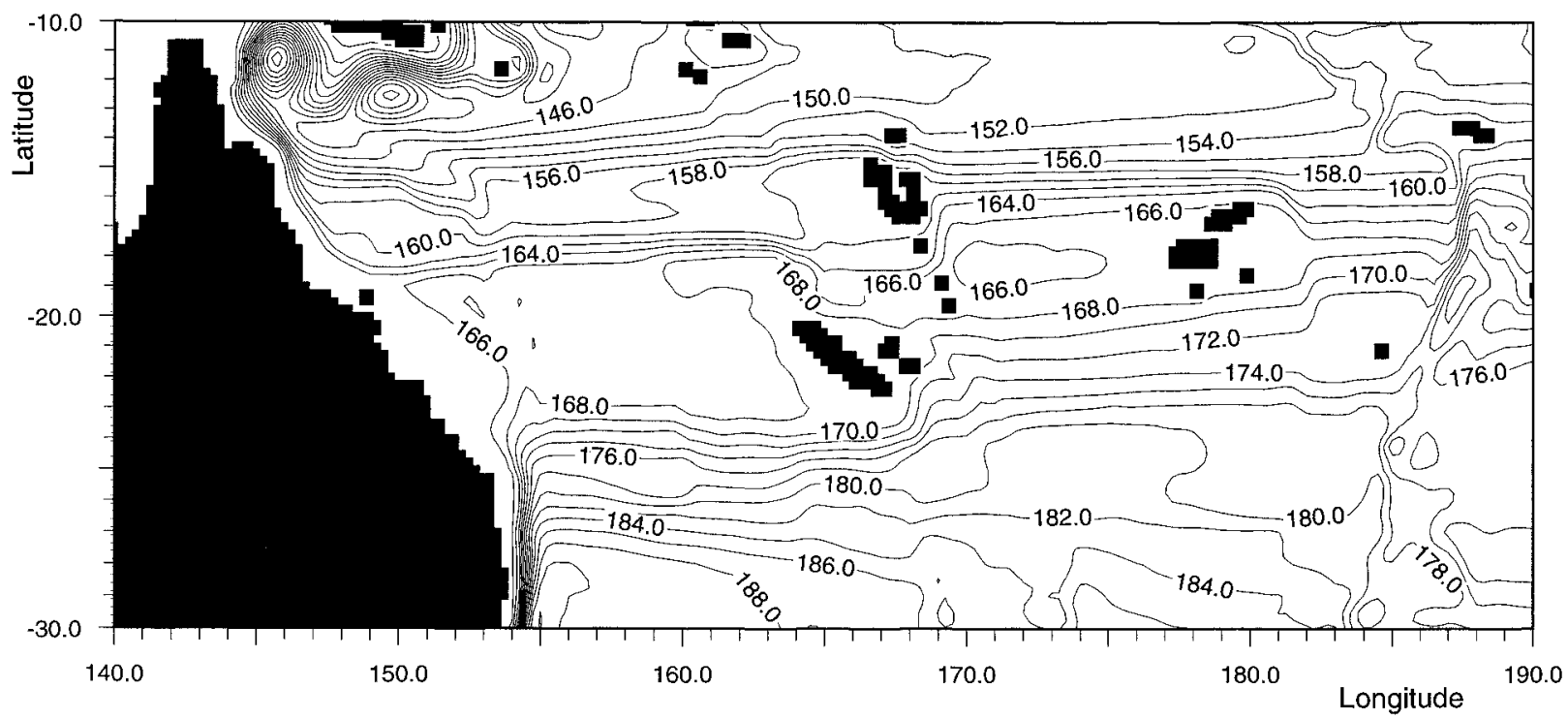

FIG. 2. The average transport stream measured in Sverdrups $\left(1 \mathrm{~Sv} \equiv 10^{6} \mathrm{~m}^{3} \mathrm{~s}^{-1}\right)$. As with the results plotted in Figs. 3-10, this is the average between years 8.0 and 12.0 of the model run. 
(a)

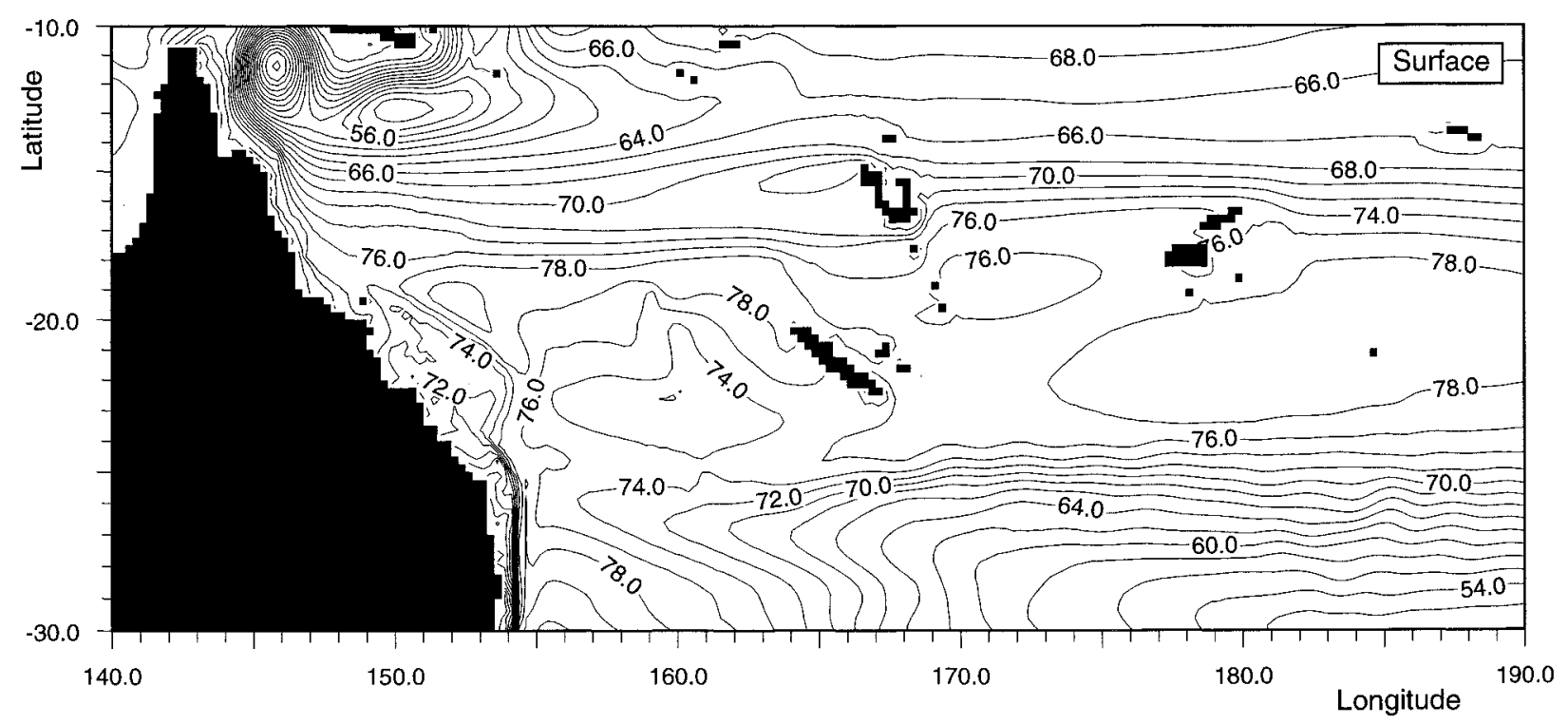

(b)

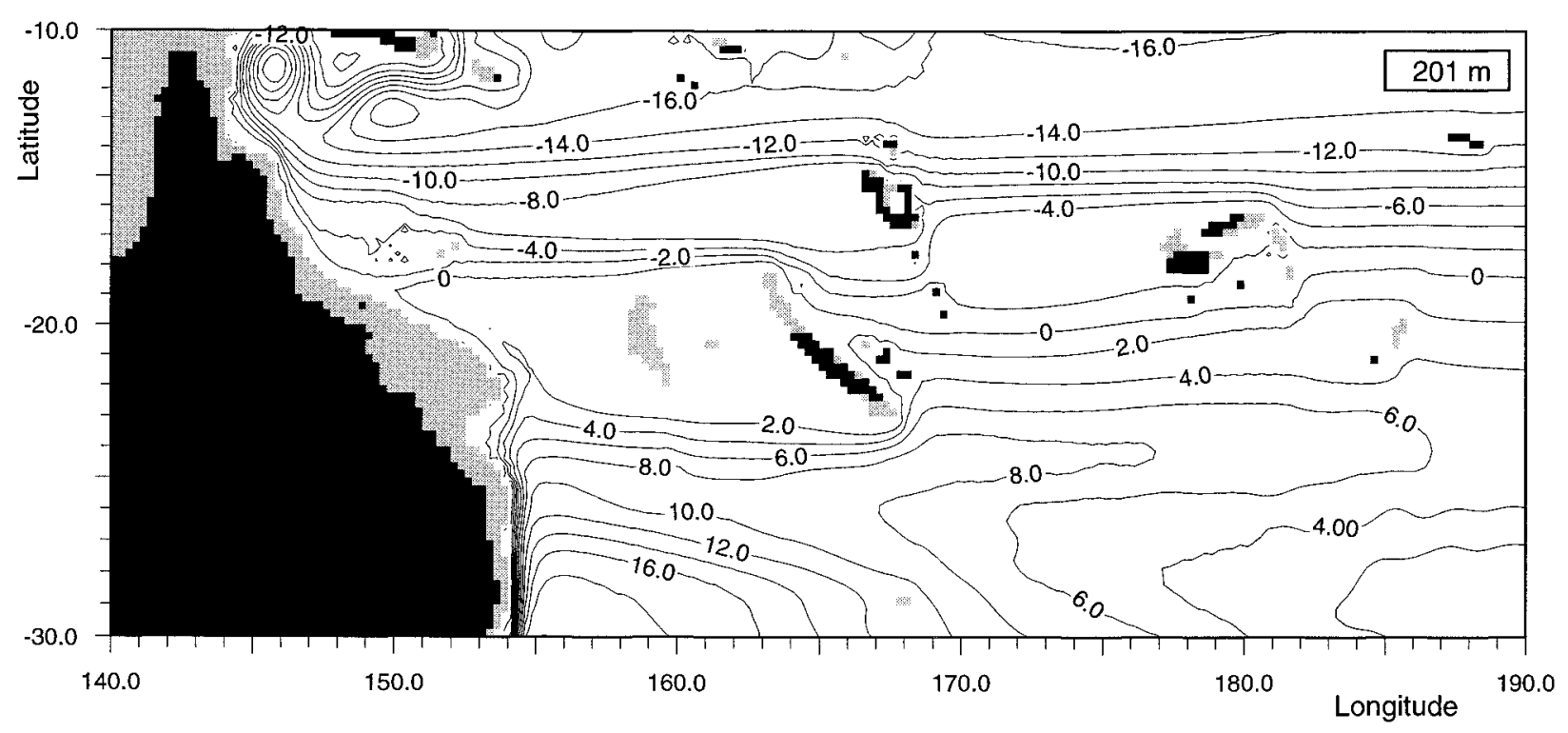

FIG. 3. (a) The average sea surface elevation. (b) Dynamic height at $201 \mathrm{~m}$ (model level 8). (c) Dynamic height at $508 \mathrm{~m}$ (level 13). (d) Dynamic height at $989 \mathrm{~m}$ (level 17).

New Caledonia (Rochford 1959a,b; Scully-Power 1973; Donguy and Hénin 1975b; Andrews and Clegg 1989). Thus Rochford (1959b) shows a high salinity core of his saline tropical water extending westward at the latitude of Espirito Santo. This appears to correlate with a narrow $10 \mathrm{~cm} \mathrm{~s}^{-1}$ westward current seen by Donguy and Hénin (1975b) at the same latitude. Rochford also finds tropical water extending to the west of the northern tip of New Caledonia, just at the latitude where ScullyPower finds a similar narrow current extending down to $900 \mathrm{~m}$.
However, with the possible exception of the Coral Sea region, the normally accepted picture of the southwest Pacific is of a broad westward flow at $500 \mathrm{~m}$ associated with the SEC, with weaker and more complex flows near the surface. What this picture omits is the possibility that there is significant blocking by the large number of island arcs and reef systems in the region (Fig. 1).

When the size of the topographic features is large compared to the Rossby radius, one would normally expect to find boundary currents on the eastern side of 
(c)

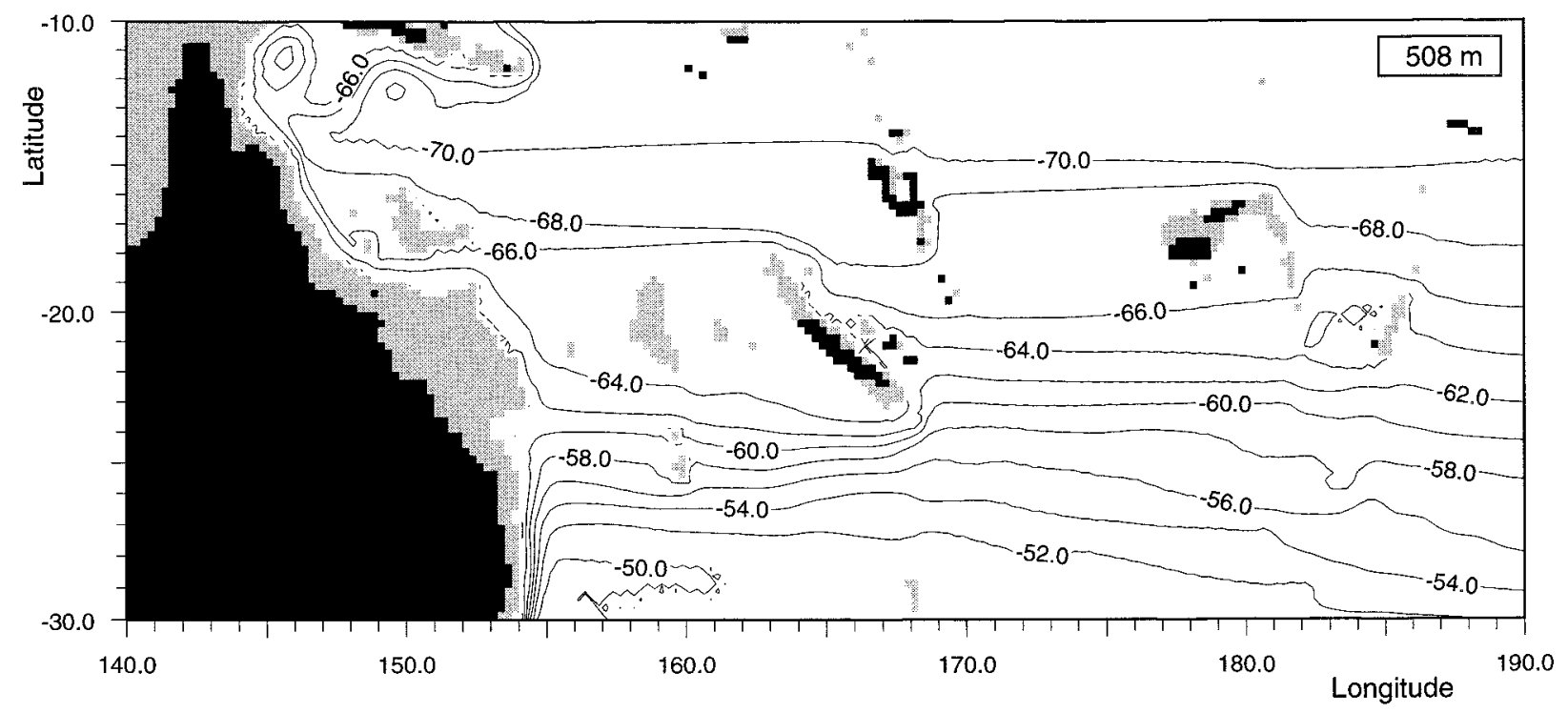

(d)

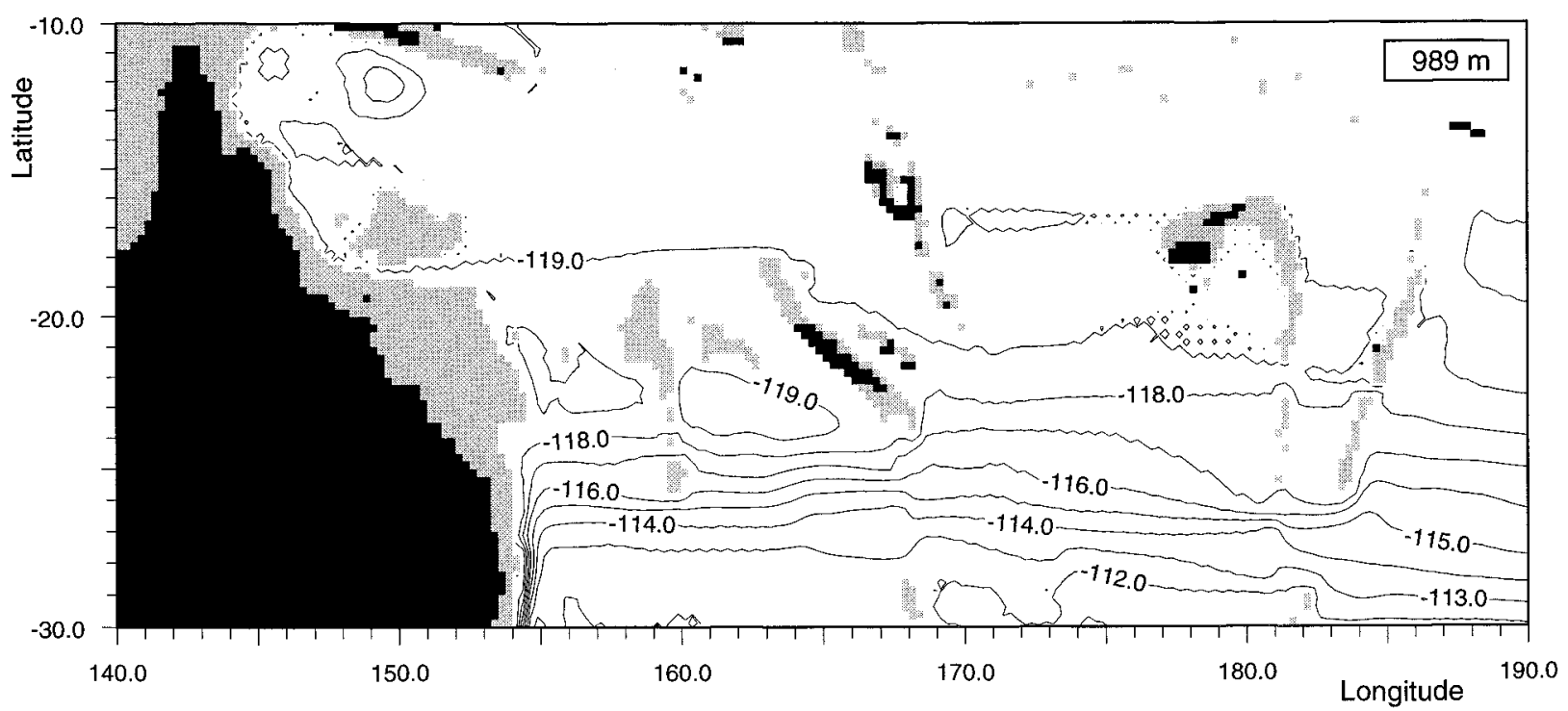

FIG. 3. (Continued)

the topography and zonal jets extending westward from the northern and southern extremities. Such flows are consistent with the detailed analysis of the Coral Sea data. They have been proposed for the Hawaiian Islands in the North Pacific (Qiu et al. 1997) and show up near New Caledonia in Hughes's (1993, Fig. 3.32a) study of the Coral Sea using a one-degree model.

The numerical model results presented here indicate that such topographically controlled flows may be widespread throughout the southwest Pacific. Because it does not resolve very short scales, the model may still be overestimating the widths of the zonal jets and under- estimating the strength of their instabilities. However, the evidence for the existence of zonal jets and boundary currents is very strong. Such features are relatively unknown and unstudied, so these results should provide a strong incentive for further detailed experimental and theoretical research in the region.

Section 2 of the paper describes the numerical model used for the present study. Section 3 presents the main model results, concentrating in particular on how the topography affects the temperature, salinity, dynamic height, and velocity fields. Section 4 compares the model results with two recent CTD sections. The paper con- 
cludes with a discussion of these comparisons and the further implications of the model results.

\section{The OCCAM model}

OCCAM is a global primitive equation level model based on the original Bryan-Cox-Semtner model (Bryan 1969; Semtner 1974, Cox 1984). The model variables are potential temperature, salinity, the two horizontal components of velocity and the sea surface height (above mean sea level). The model uses an ArakawaB grid (Mesinger and Arakawa 1976) because of its superior performance of representing the propagation of short Rossby waves and fronts.

The model includes a number of developments of the basic Bryan-Cox-Semtner code to make it computationally efficient and to better represent ocean physics. The developments include a free surface, a proper representation of rainfall and evaporation, improved advection schemes (Webb 1995; Webb et al. 1998a,b), and a double grid structure to allow improved representation of the Arctic Ocean. The internal organization of the code has been changed so that it can run efficiently on modern high performance array processor computers using message passing (Webb 1996). Further details are given in Webb et al. (1998a).

The Coral Sea results discussed here come from a 14-yr run of the global ocean model using a horizontal resolution of $1 / 4$ degree. One advantage of using a global model is that it is not affected by the errors at the open boundaries, which affect regional models. However the computational cost is high, thus until there is a further improvement in available computer power, significantly longer runs are not possible.

The model used Pacanowski and Philander (1981) vertical mixing for the tracer fields. For the velocity field, the model used Laplacian mixing with a coefficient of $1 \mathrm{~cm}^{2} \mathrm{~s}^{-1}$. Laplacian mixing was also used to represent horizontal diffusion and viscosity with coefficients of $1 \times 10^{6} \mathrm{~cm}^{2} \mathrm{~s}^{-1}$ and $2 \times 10^{6} \mathrm{~cm}^{2} \mathrm{~s}^{-1}$, respectively. Saunders et al. (1999) show that the model's sea surface height variability in the east Pacific is similar to that for the $1 / 4$ degree Parallel Ocean Program (POP) model (McClean et al. 1997), which uses biharmonic friction.

Model depths were set to the median value of the $1 / 12$ degree U.S. Navy DBDB5 dataset in each model grid square. Manual checking of key sills and channels were also performed (Thompson 1995). The potential temperature and salinity fields were initialized from the Levitus global annual average dataset (Levitus 1982). The velocity field was initially set to zero.

The model was then run, forced by a monthly wind stress from a 1986-88 ECMWF climatology (Siefridt and Barnier 1993). The flux of heat at the surface was represented by relaxing the 20-m-thick surface layer of the model to the Levitus (1994) monthly values with a relaxation time of 30 days. The net effect of evaporation
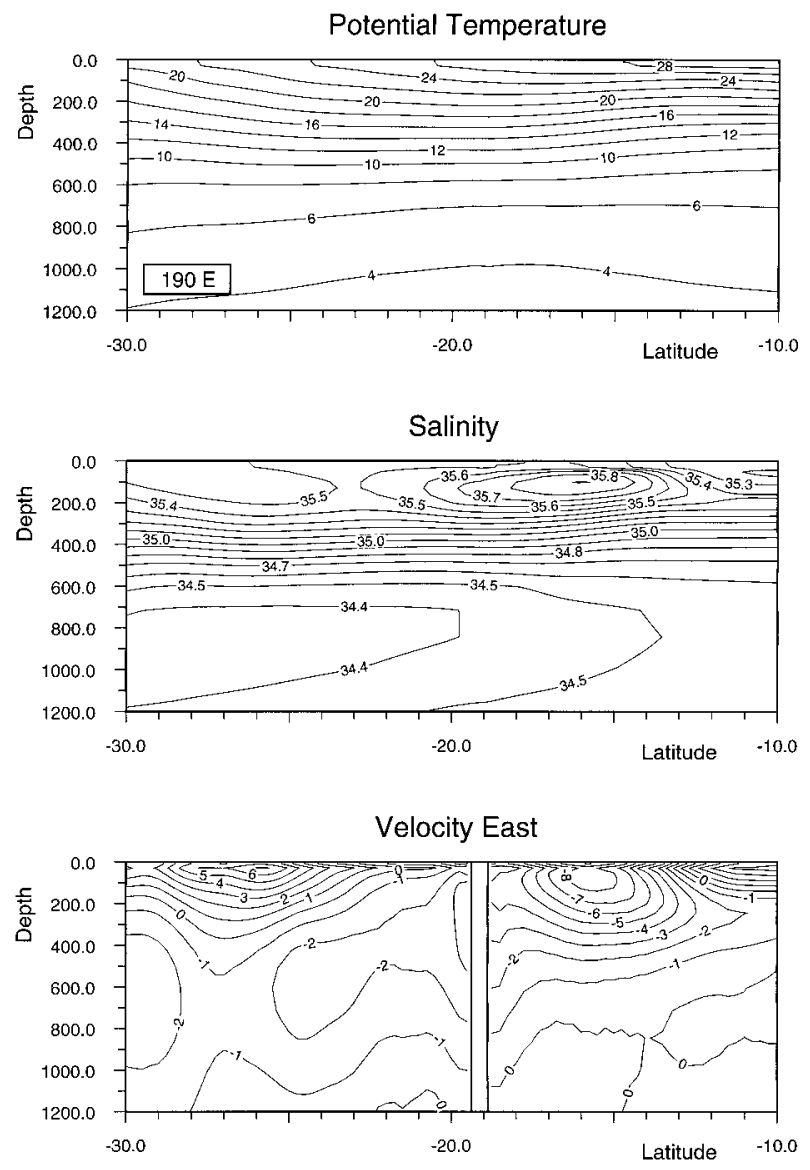

FIG. 4. Potential temperature, salinity, and eastward velocity at $190^{\circ} \mathrm{E}$.

and precipitation was represented by changing the sea surface height in such a way that, after conserving salinity, the salinity of the surface grid box converged on the Levitus value with the same relaxation time. Saunders et al. (1999) compare the model heat and freshwater fluxes in the Pacific with the NCEP-STR climatology of Doney et al. (1998). The overall agreement is reasonable. At $20^{\circ} \mathrm{S}$ the differences, which are of order 10 $\mathrm{W} \mathrm{m}^{-2}$, are comparable with the errors in observed fluxes.

The model was spun up for seven model years after which the main analysis period started. The results presented in this paper come from years 8.0 to 12.0 of the model run. Instantaneous snapshots taken during the model run show the same general behavior.

\section{Current structures in the Coral Sea}

\section{a. The vertically integrated transport}

Figure 2 shows the transport streamfunction calculated from the mean model velocities averaged over years 8-12 inclusive of the model run. It provides an overview of the vertically averaged flow but is complicated because it includes the effect of both the near- 
surface flows and the deep boundary currents. The former are driven primarily by the surface wind field, precipitation, and evaporation in neighboring regions of ocean. The latter are part of the larger-scale deep thermohaline circulation.

In the region north of $28^{\circ} \mathrm{S}$ total transport is dominated by the mean westward flow associated with the SEC. This is strongest near $17^{\circ} \mathrm{S}$. On reaching the Australian coast the mean flow north of $22^{\circ} \mathrm{S}$ turns northward and feeds the North Queensland Current and eventually the New Guinea Coastal Undercurrent.

South of $22^{\circ} \mathrm{S}$ the mean flow turns south and joins the East Australian Current (EAC). This forms a tight recirculation gyre near $32^{\circ} \mathrm{S}$. The figure also shows an associated local gyre, extending to $200^{\circ} \mathrm{E}$ (longitude in degrees azimuth eastward from Greenwich). This appears to be equivalent to the local maximum in the South Pacific Sverdrup Gyre discussed by de Szoeke (1987).

As is discussed later, many of the north-south shifts in the currents are due to topography acting on the nearsurface currents. However, near $185^{\circ} \mathrm{E}$ there is a deep western boundary current associated with the Kermadec-Tonga Trench. Saunders et al. (1999) have recently shown this deep flow in the model compares well with observations.

\section{1) DyNAMiC HEIGHTS AT THE SURFACE}

The sea surface height, $\zeta(x)$, from the model and the dynamic heights at $201.1 \mathrm{~m}, 508.2 \mathrm{~m}$, and $989.4 \mathrm{~m}$ are shown in Fig. 3. The dynamic height $\eta(x, z)$ is given by

$$
\eta(x, z)=\zeta(x)-\frac{1}{\rho_{0}} \int_{z}^{0} d z^{\prime} \rho\left(T, S, z^{\prime}\right),
$$

where $T$ is potential temperature, $S$ salinity, $x$ horizontal position, $z$ depth, $\rho$ density, and $\rho_{0}$ a reference density $\left(1024 \mathrm{~kg} \mathrm{~m}^{-3}\right)$.

At the surface the model shows the SEC flowing westward between $12^{\circ} \mathrm{S}$ and $22^{\circ} \mathrm{S}$. Most of the current flows north of Fiji with speeds of order $15 \mathrm{~cm} \mathrm{~s}^{-1}$. However there is also a weak flow south of the island. The dynamic height difference across the $S E C$ is about $10 \mathrm{~cm}$.

At $170^{\circ} \mathrm{W}$ the northern branch current splits to pass north and south of the Vanuatu islands. There is a weak recirculation to the southeast of the islands and in the lee of the islands, but thereafter the flow is continuous until it reaches Australia where most turns north in the North Queensland Current.

The weak westward flowing branch south of Fiji extends from $18^{\circ} \mathrm{S}$ to $22^{\circ} \mathrm{S}$. Some recirculation to the south joins the eastward flowing current at $27^{\circ} \mathrm{S}$. The rest flows north of New Caledonia where it joins a weak gyre centered between the island and the Australian coast.

North of these westward flows the model shows the eastward flowing South Equatorial Countercurrent (SECC). This has maximum speeds of about $10 \mathrm{~cm} \mathrm{~s}^{-1}$
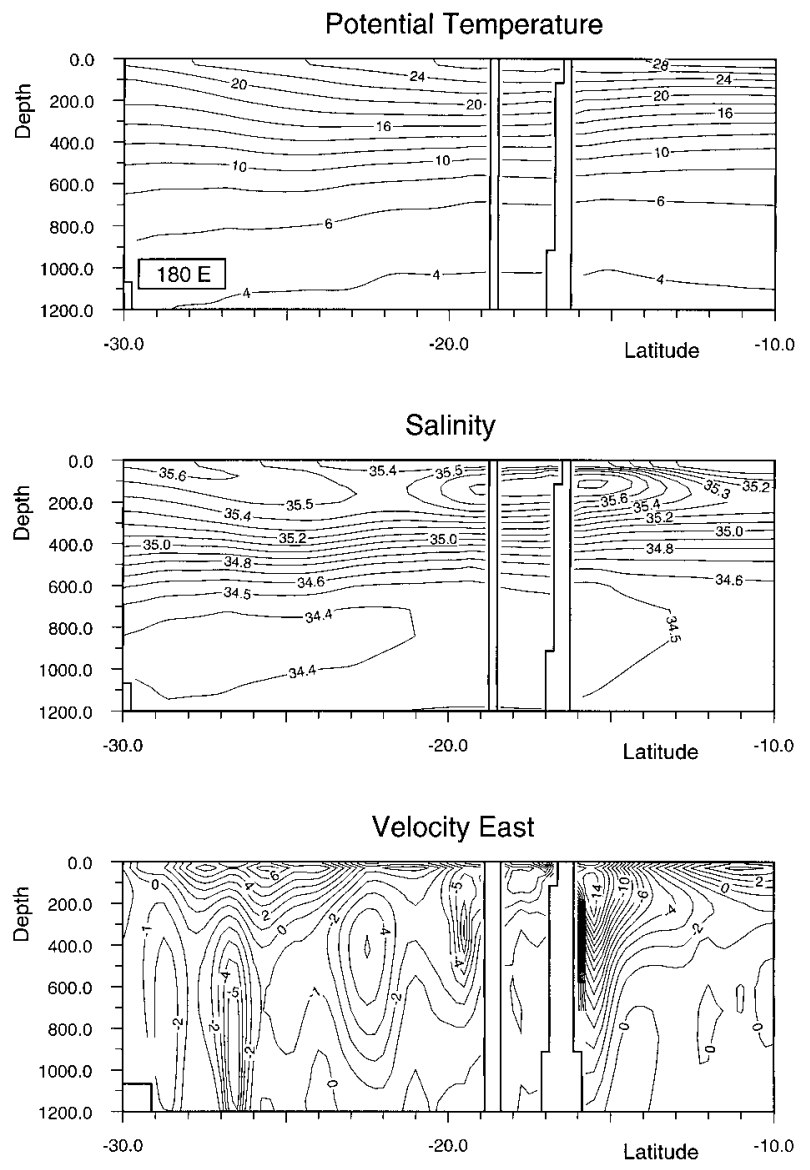

FIG. 5. Potential temperature, salinity, and eastward velocity at $180^{\circ} \mathrm{E}$.

near $5^{\circ} \mathrm{S}$ (outside the region plotted here) but, as shown in Fig. 3a, it extends as far south as $14^{\circ} \mathrm{S}$. To the south there is the strong (unnamed) eastward flowing current centered at $26^{\circ} \mathrm{S}$ with velocities of order $8 \mathrm{~cm} \mathrm{~s}^{-1}$. To the west, near the Australian coastline, this is reduced in strength, possibly due to the strong recirculation gyre associated with the EAC between $26^{\circ} \mathrm{S}$ and $33^{\circ} \mathrm{S}$. To the east (Fig. 4), the transport increases, the current broadens, and it forms the southern branch of the normal subtropical gyre of the South Pacific.

\section{2) DyNAMiC HEIGHTS AT $200 \mathrm{M}$}

The dynamic heights for the center of the layer near $200 \mathrm{~m}$ are shown in Fig. 3b. At $175^{\circ} \mathrm{E}$, the SECC has almost disappeared, the SEC north of Fiji is little changed, but south of Fiji it has become much stronger and extends to $24^{\circ} \mathrm{S}$. On reaching New Caledonia the flow splits, forming western boundary currents along the continental shelf and a pair of strong jets to the north and south of the island. As a result by $160^{\circ} \mathrm{E}$, the SEC has split into three jets, a Northern Vanuatu Current, a Northern New Caledonia Current, and a Southern New Caledonia Current. These broaden slightly as they con- 

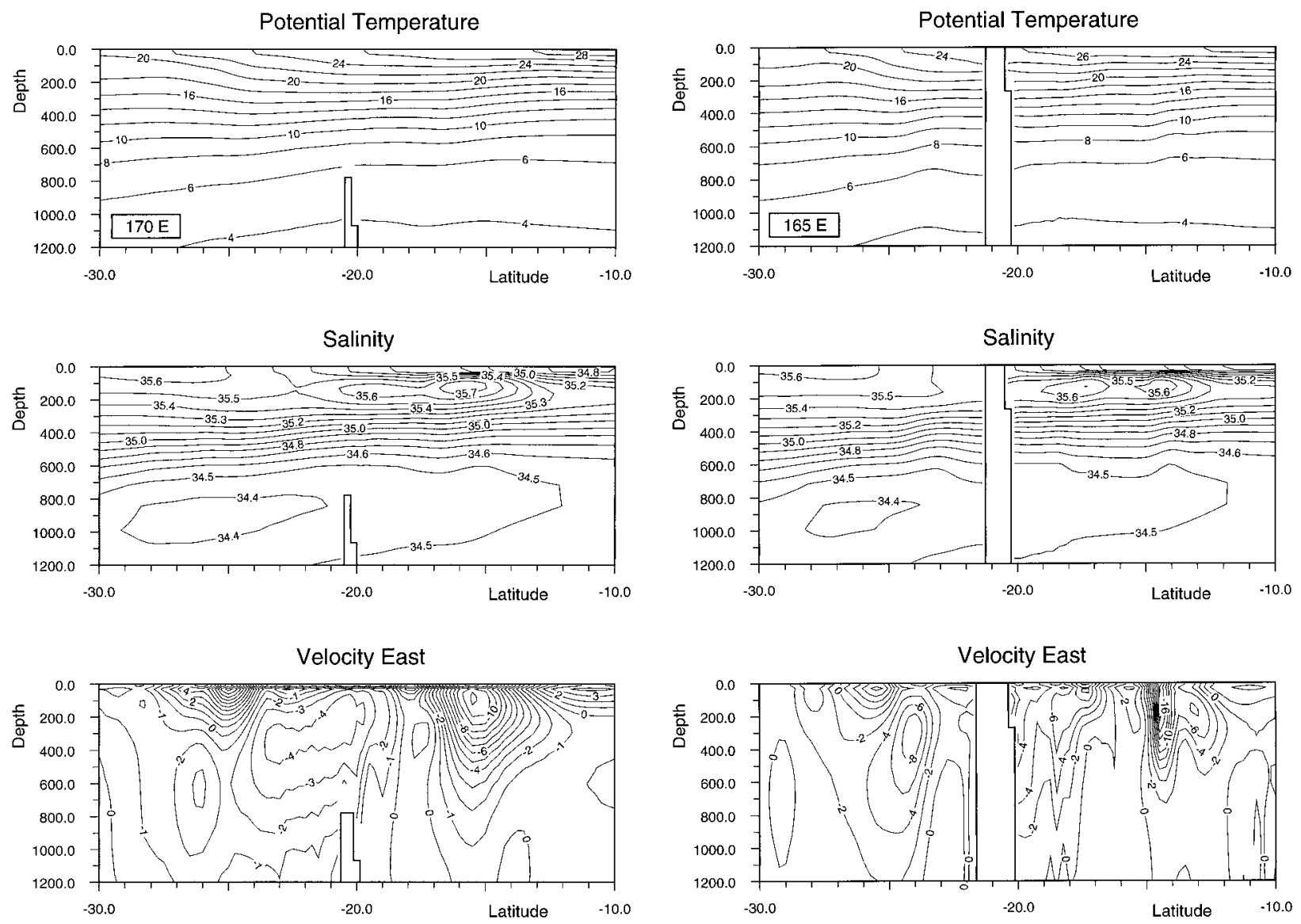

FIG. 6. Potential temperature, salinity, and eastward velocity at $170^{\circ} \mathrm{E}$.

tinue westward to the Australian coast. This broadening of zonal jets is discussed by Webb (1993).

Compared with the surface flow, there is also a major change to the unnamed eastward flowing current found at $25^{\circ} \mathrm{S}$. Instead of starting near the Australian coastline, this now starts near $165^{\circ} \mathrm{E}$ and is much weaker.

\section{3) Dynamic height at $500 \mathrm{M}$}

The dynamic height at $500 \mathrm{~m}$ is shown in Fig. 3c. At $175^{\circ} \mathrm{E}$ the flow at all latitudes is now dominated by the SEC. In the north the SECC has disappeared. The mean position of the SEC has moved southward but the total dynamic height difference across the current has remained constant at $20 \mathrm{~cm}$.

One result of the southward shift of the SEC is that the branch flowing to the north of Fiji is much weaker. A second is that most of the current passes south of New Caledonia and enters the EAC. The EAC recirculation gyre has also disappeared.

The figure also shows more of the underlying topography and its blocking effect on the flow field. One example is the island arc associated with Tonga, which affects the flow near $20^{\circ} \mathrm{S}, 186^{\circ} \mathrm{E}$ and also near $25^{\circ} \mathrm{S}$,

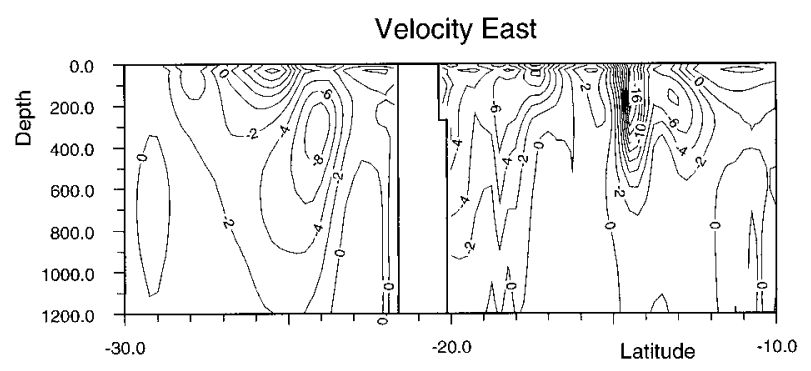

FIG. 7. Potential temperature, salinity, and eastward velocity at $165^{\circ} \mathrm{E}$.

$184^{\circ} \mathrm{E}$. The Lau Ridge, southeast of Fiji has a similar effect at $18^{\circ} \mathrm{S}, 182^{\circ} \mathrm{E}$ as does the southeast extension of the Vanuatu islands at $17^{\circ} \mathrm{S}, 169^{\circ} \mathrm{E}$.

The reefs associated with New Caledonia also block the flow as do Kelso Bank $\left(25^{\circ} \mathrm{S}, 160^{\circ} \mathrm{E}\right)$ and the Queensland Plateau $\left(17^{\circ} \mathrm{S}, 151^{\circ} \mathrm{E}\right)$. However the extensive reef systems near $20^{\circ} \mathrm{S}, 160^{\circ} \mathrm{E}$ lie in the lee of New Caledonia and so have no effect on the zonal currents.

\section{4) Dynamic height at $1000 \mathrm{M}$}

At depths near $1000 \mathrm{~m}$ the dynamic height difference across the current has dropped to $7 \mathrm{~cm}$ (Fig. 3d). There is still a small flow joining the North Queensland Current but the main branch of the SEC lies south of both Fiji and New Caledonia and feeds the EAC.

Because of the southward shift of the current axis, Fiji, Vanuatu, and New Caledonia produce only a limited blocking effect. Instead, the ridges south of Samoa near $24^{\circ} \mathrm{S}, 184^{\circ} \mathrm{E}$ and the Lau ridge south of Fiji become important and help steer the current farther south.

\section{b. North-south sections}

The dynamic height plots show that the large-scale behavior of the SEC is very similar to that proposed 

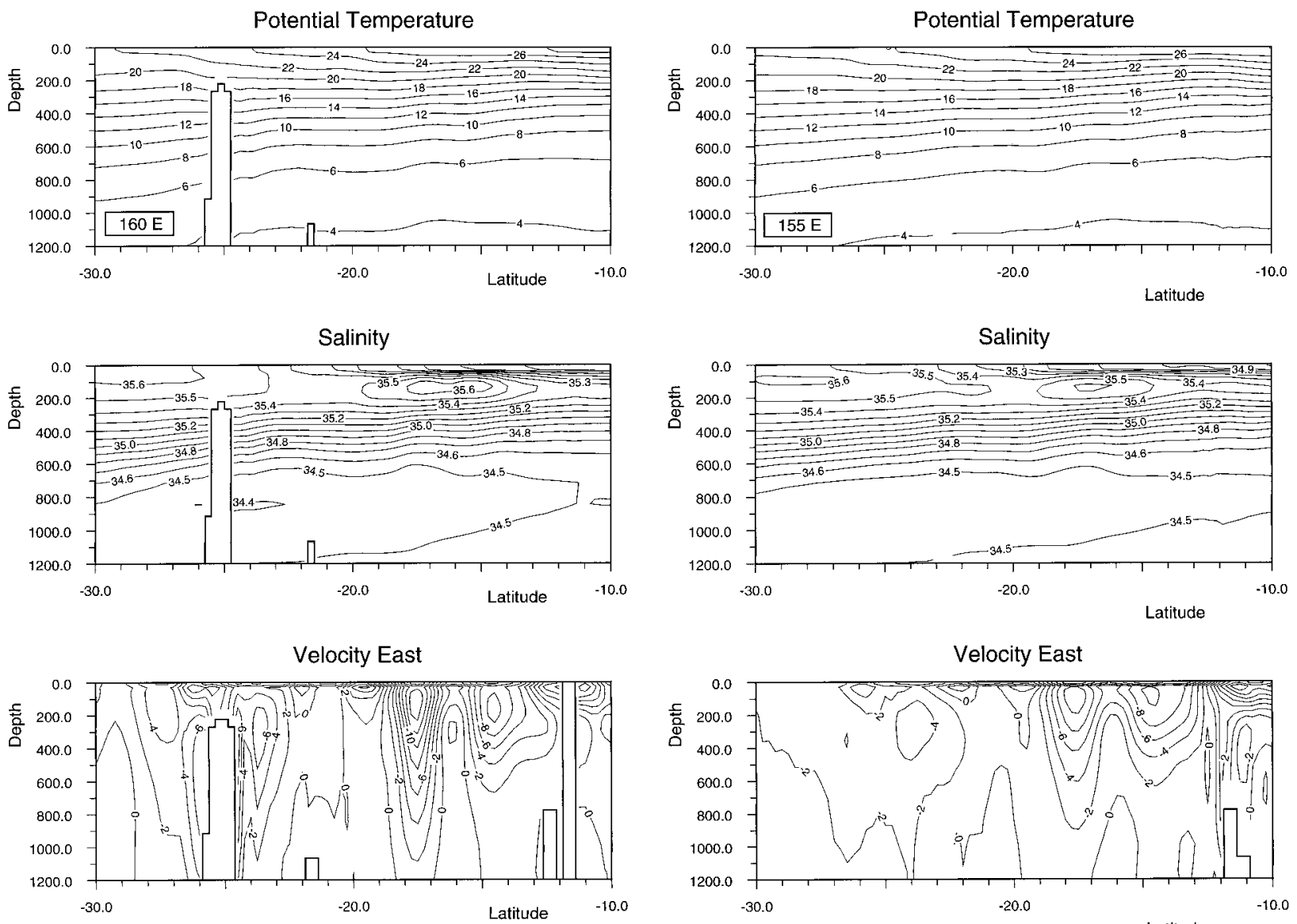

FIG. 8. Potential temperature, salinity, and eastward velocity at $160^{\circ} \mathrm{E}$.

by Reid (1986, 1997) with the axis of the current moving southward with depth. However at small scales the model shows a much more complex behavior with the topography forming a series of relatively narrow western boundary currents and zonal jets.

To investigate the effect on the flow further, we consider six north-south sections, taken from the model, of potential temperature, salinity, and westward component of velocity. The sections, which are at $190^{\circ} \mathrm{E}, 180^{\circ} \mathrm{E}$, $170^{\circ} \mathrm{E}, 165^{\circ} \mathrm{E}, 160^{\circ} \mathrm{E}$, and $155^{\circ} \mathrm{E}$, are shown in Figs. 4-9.

\section{1) Sections at $190^{\circ} \mathrm{E}$ And $180^{\circ} \mathrm{E}$}

Figure 4 shows the section at $190^{\circ} \mathrm{E}$. The velocity field is complicated by the surface Ekman layer, but below this the core of the SEC is observed at $16^{\circ} \mathrm{S}$. Maximum velocities occur near $100 \mathrm{~m}$ where they exceed $8 \mathrm{~cm} \mathrm{~s}^{-1}$. The core of the current occurs at lower depths to the north and south, reaching $250 \mathrm{~m}$ at $10^{\circ} \mathrm{S}$ and $650 \mathrm{~m}$ at $26^{\circ} \mathrm{S}$.

The core of the current is also associated with salinities above 35.8 psu advected from the high salinity

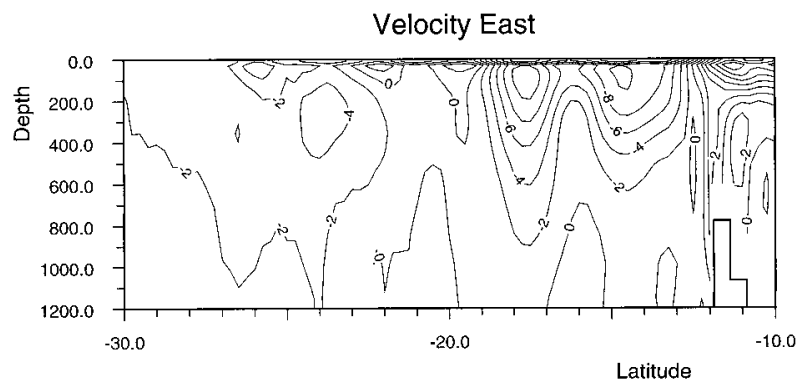

FIG. 9. Potential temperature, salinity, and eastward velocity at $155^{\circ} \mathrm{E}$.

surface region centered at $120^{\circ} \mathrm{W}$. This may have some effect on the dynamics but, as we shall see, the high salinity is a useful tracer for following the current farther west. Deeper in the water column, near $900 \mathrm{~m}$, low salinity intermediate water intrudes from the south. This is carried westward by the deep extension of the SEC.

The temperature field has less structure but it shows a divergence of the isotherms toward the south, with both outcropping of near-surface isotherms and deepening of those below $8^{\circ} \mathrm{C}$. The outcropping region is associated with the eastward surface current at $26^{\circ} \mathrm{S}$ discussed earlier. This has maximum of $8 \mathrm{~cm} \mathrm{~s}^{-1}$ but, unlike the SEC, it is an isolated surface feature and is not connected to any deeper structure. Thus, although the behavior of the SEC fits Reid's hypothesis that the gyre moves south with depth, this shallow surface current seems to be an isolated feature, which may be independent of the main gyre circulation.

In contrast to the section at $190^{\circ} \mathrm{E}$, the section at $180^{\circ} \mathrm{E}$ (Fig. 5) shows a complex current structure due to the blocking of the SEC by the Fiji Islands, and the island arcs associated with the Tonga Trench and the Lau Rise. There are five primary westward jets, the 
(a)

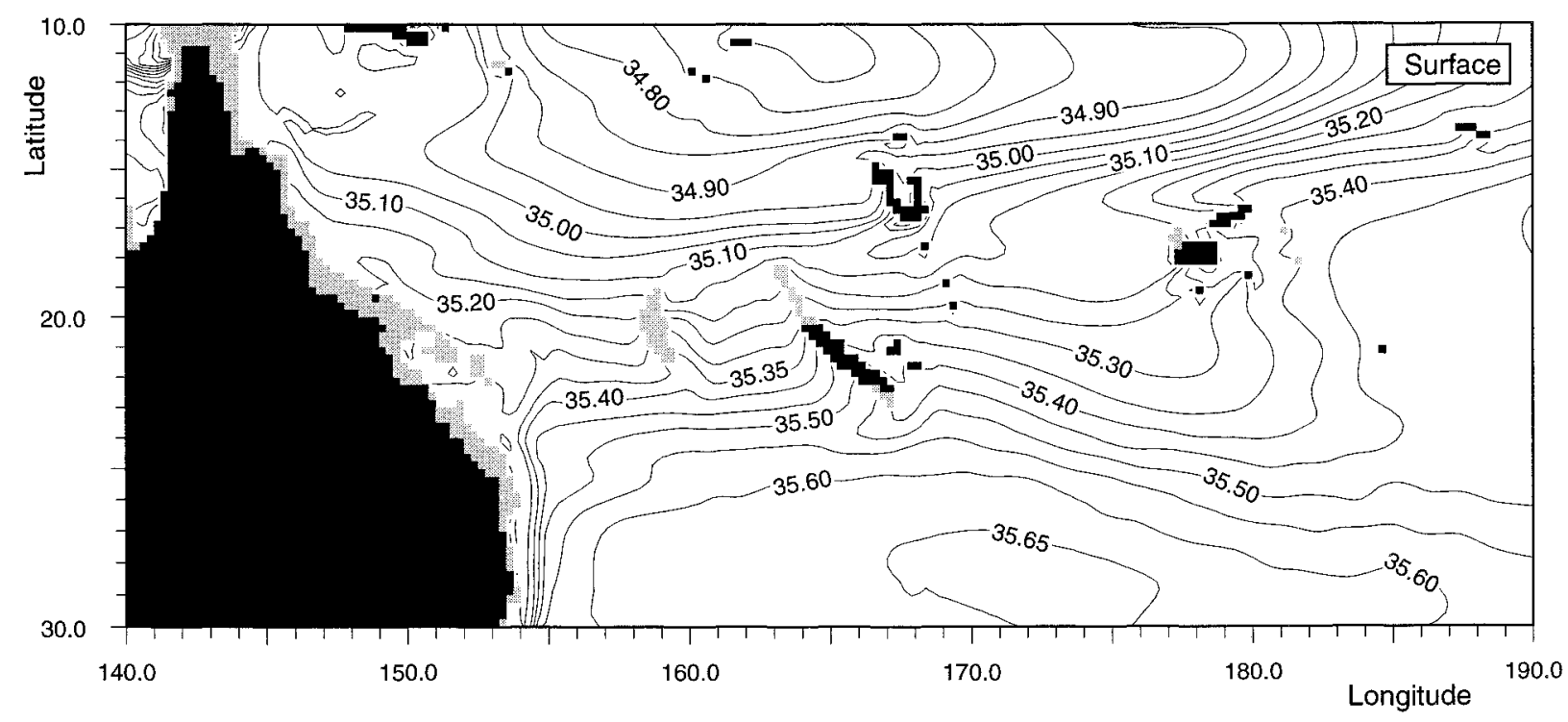

FIG. 10. Salinity at the surface (model level 1). (b) Salinity at $131 \mathrm{~m}$ (level 6). (c) Salinity at $845 \mathrm{~m}$ (level 16).

North Fiji Current at $15^{\circ} \mathrm{S}$ having the shallowest core, the strongest core velocities, and the deepest extent. This jet is also connected to the shallow, 300-m depth, extension of the SEC, which underlies the Equatorial Counter Current.

A second, much weaker jet lies at $19.5^{\circ} \mathrm{S}$. As shown in the dynamic height plots at 200 and $500 \mathrm{~m}$, this is associated with a flow to the north of the Tonga Islands and to the south of the Fiji Islands.

The third jet at $22.5^{\circ} \mathrm{S}$ is associated with a $1000 \mathrm{~m}$ sill in the Tonga Ridge at $22^{\circ} \mathrm{S}$ near Ata Island. At these latitudes the Lau Ridge also has topography near $1000 \mathrm{~m}$.

Finally the two deep jets in the south are associated with the gap between the Kermadec and Tonga Ridges. The flow is then further split by the Colville Ridge and flows through the gap in the Colville Ridge at $28.5^{\circ} \mathrm{S}$ and between the Colville and Lau Ridges at $26.5^{\circ} \mathrm{S}$.

The effect of the jets on the tracer fields is most noticeable in the plot of salinity where the two northern jets appear to be responsible for high salinities found between $12^{\circ} \mathrm{S}$ and $22^{\circ} \mathrm{S}$ at a depth of $100 \mathrm{~m}$. Above this, the near-surface salinities are much lower than at $190^{\circ} \mathrm{E}$. The 35.4 psu contour also extends farther to the south where it reaches the region of eastward flow near $24^{\circ} \mathrm{S}$.

The influence of the deeper westward jets on the tracer fields is less obvious. They are responsible for changes in slope of both the temperature and salinity isolines, but these are so small that, if seen in observational data, they would normally be attributed to noise.

\section{2) Sections at $170^{\circ} \mathrm{E}$ And $165^{\circ} \mathrm{E}$}

In the section at $170^{\circ} \mathrm{E}$ the westward jets are seen to have broadened and to a certain extent combined. The strongest flow is still in the north at $15.5^{\circ} \mathrm{S}$, a continuation of the North Fiji Current, where current speeds reach $12 \mathrm{~cm} \mathrm{~s}^{-1}$. South of this, the South Fiji Current at $19.5^{\circ} \mathrm{S}$ and the jet at $22.5^{\circ} \mathrm{S}$ have spread and combined to form a broad subsurface flow. The same has happened to the jets at $26.5^{\circ} \mathrm{S}$ and $28.5^{\circ} \mathrm{S}$, but the greater transport in the latter means that it dominates the combined flow.

The salinity field again shows a maximum in the core of the North Fiji Current but the maximum contour has dropped from 35.9 to $35.7 \mathrm{psu}$. There is also a weak secondary maximum associated with the extension of the South Fiji Current. Above this maximum, the surface salinities have dropped farther to 35.2 psu and less, but the southward penetration of the low salinity surface water is reduced. Instead there is greater penetration of 35.6 psu water from the south.

This high salinity surface water is bounded to the north by the core of the shallow eastward flowing current at $25^{\circ} \mathrm{S}$. This has maximum speeds of over $7 \mathrm{~cm}$ $\mathrm{s}^{-1}$ at $180^{\circ} \mathrm{E}$ increasing to $10 \mathrm{~cm} \mathrm{~s}^{-1}$ at $170^{\circ} \mathrm{E}$.

At $165^{\circ} \mathrm{E}$ there is a further major change in the structure of the jets that results from blocking by Vanuatu, New Caledonia, and the Norfolk Ridge. In the north of the section, the jet at $14.5^{\circ} \mathrm{S}$ is formed when the North Fiji Current is blocked by the Vanuatu group. Part of the flow turns northward until it reaches the gap between Espiritu Santo and Banks Island when it again turns westward to form the jet.

The remainder of the North Fiji Current turns to the south, eventually forming the second jet near $18^{\circ} \mathrm{S}$. The high salinity cores advected by these currents are compared with observations later in the paper.

Further south, the South Fiji Current is blocked by New Caledonia. Part of the current turns northward to 
(b)

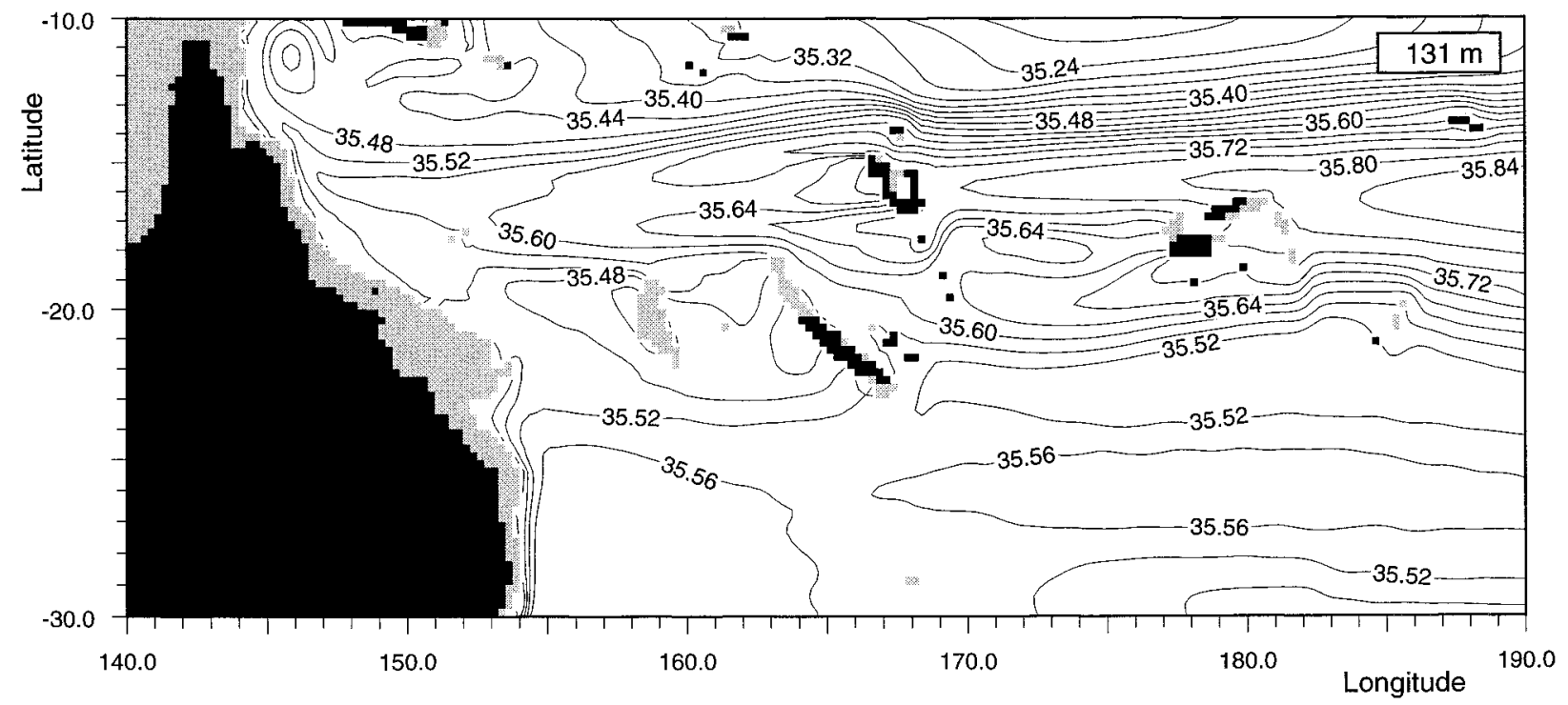

(c)

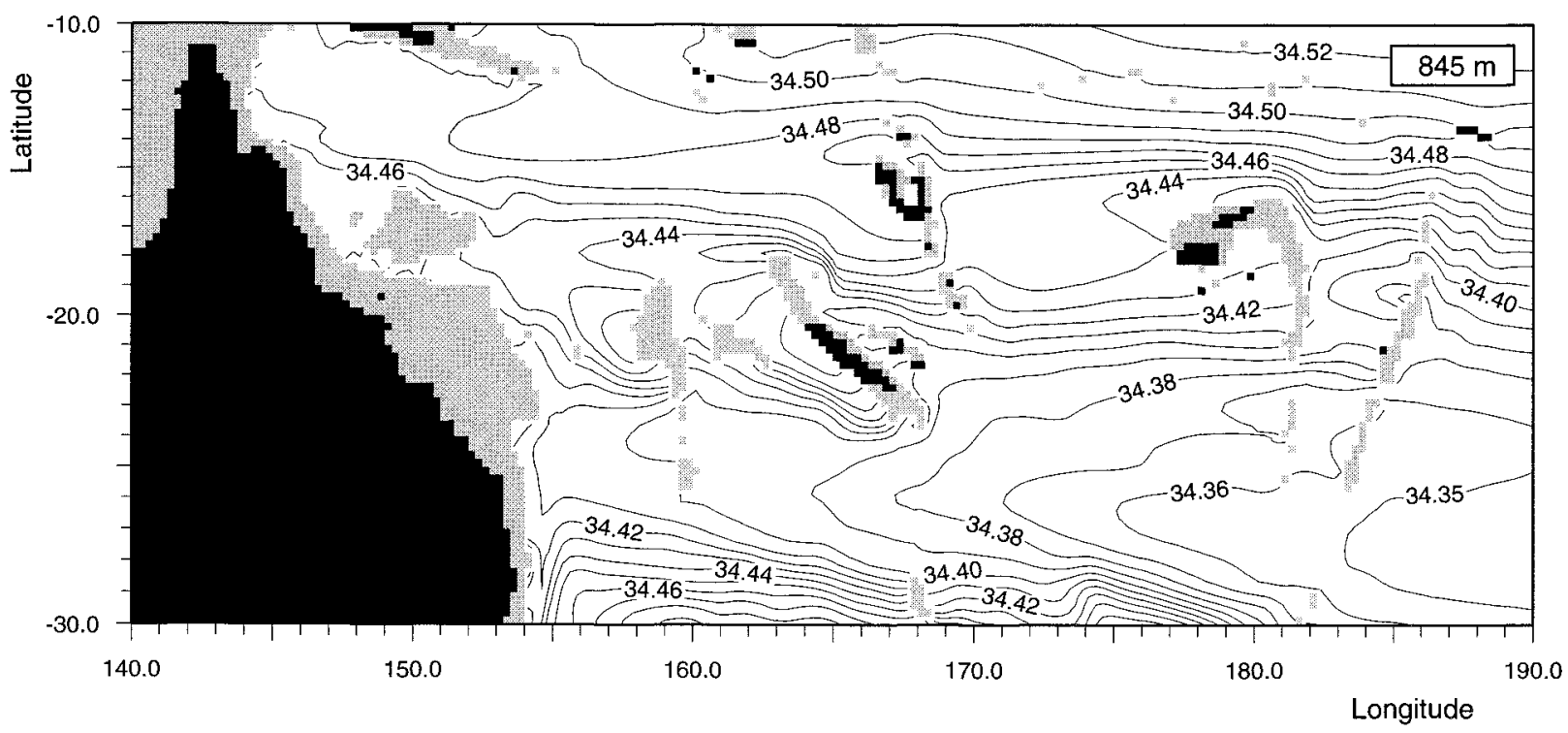

FIG. 10. (Continued)

form the boundary current seen on the section at $20^{\circ} \mathrm{S}$. The remainder turns south where it passes through a gap between New Caledonia and the Norfolk Ridge to form the southernmost jet at $24^{\circ} \mathrm{S}$.

\section{3) Sections At $160^{\circ} \mathrm{E}$ And $155^{\circ} \mathrm{E}$}

Further changes are found at $160^{\circ} \mathrm{E}$. At $17.5^{\circ} \mathrm{S}$, a new jet has been formed by the blocking effect of New Caledonia and the D'Entrecasteaux Reefs. Farther north, at $14^{\circ} \mathrm{S}$, the North Vanuatu Current has become broader and weaker.

Both flows contain water that has come from both the North Fiji jets so subsurface salinities remain high. The maximum salinity contour has dropped to $35.6 \mathrm{psu}$, but above it surface salinities have dropped farther to 34.9 psu.

The third jet at $24^{\circ} \mathrm{S}$ is a continuation of the South New Caledonia Current. The core of this current can pass through the gap between the Argo and Kelso Banks 
$\left(159.5^{\circ} \mathrm{E}\right)$ without any change in latitude. However the southward extension of this flow, which now also includes water from the $26^{\circ} \mathrm{S}$ core at $170^{\circ} \mathrm{E}$, is blocked by the Capel Bank and results in two new branches. At $160^{\circ} \mathrm{E}$ the northern branch forms a western boundary current running northwestward along the flank of the topography. Near $900 \mathrm{~m}$ these southern jets continue to advect low salinity from the east, the lowest salinities being found just to the north of the Kelso Bank.

Farther west at $155^{\circ} \mathrm{E}$ similar structures are found but the jets are wider, the southern jets near $24^{\circ} \mathrm{S}$ have combined to form a single core, and maximum velocities are reduced. The model still shows a high salinity core at depths between 100 and $200 \mathrm{~m}$ and latitudes between $14^{\circ} \mathrm{S}$ and $19^{\circ} \mathrm{S}$, lying below low salinity surface water. However the core of low salinity water near $900 \mathrm{~m}$ and $25^{\circ} \mathrm{S}$ has become so diffuse that it no longer shows up in the contours.

\section{4) THE SALINITY FIELD}

These north-south sections from the model indicate that salinity may be a useful tracer for finding evidence for the jets in observations. To investigate the distribution of salinity further, Fig. 10 shows the salinity field at the surface and at depths of 131 and $845 \mathrm{~m}$. The latter two levels are chosen to illustrate the salinity maximum associated with the subtropical lower water and the minimum associated with southeast Pacific Intermediate Water.

The surface salinities from the model are similar to those of Reid (1997). In particular the model shows the band of low surface salinities found near the equator and second band of low values extending east-southeast from New Guinea.

The most noticeable differences from Reid's analysis occur at small scales where the model shows evidence of the jet structures in the velocity field. This is most noticeable north of Fiji where the model shows a core of high salinity water being advected from the east. Similar but smaller features are also seen to the north and south of Vanuatu and to the south of New Caledonia.

These features become much more obvious at a depth of $131 \mathrm{~m}$. The North Fiji Current is identified by a strong salinity anomaly that is split into two further jets by the Vanuatu Islands. Farther west the model shows the two jets slowly combining, but the anomaly remains very noticeable as far as the Australian coastline.

The South Fiji Current also produces a large salinity anomaly that can be followed as far as Vanuatu. Here it combines with water from the more saline North Fiji Current. The other current features described previously are not so noticeable at this level. However the current extending westward from the southern tip of New Caledonia is probably responsible for the salinity front observed in the same region.

At $845 \mathrm{~m}$, the model shows intermediate water entering from the east on a broad front near $28^{\circ} \mathrm{S}$. As it progresses westward the salinity maximum moves northward, reaching the Australian continental shelf near $25^{\circ} \mathrm{S}$. Here the main core appears to turn south but a significant fraction travels northward along the outer edge of the Barrier Reef.

The tongue of low salinity water also shows some smaller-scale structure, which may be significant. Thus near $23^{\circ} \mathrm{S}, 181^{\circ} \mathrm{E}$ a secondary tongue develops in the region of the Minerva Reefs. There is also a secondary tongue extending northwestwards along the east coast of New Caledonia. On reaching the northern limit of the island the tongue turns west, forming a narrow tongue, which can be followed to the Australian Coast.

Further tongues of low salinity water are observed just to the west of the Tonga Islands $\left(19^{\circ} \mathrm{S}, 185^{\circ} \mathrm{E}\right)$, in the North Fiji Current and at the start of the North Vanuatu Current.

\section{Comparisons with observations}

In the past, the most detailed analyses of the physical oceanography of the region have concentrated on the Coral Sea. Here Rochford (1959a,b) using bottle data finds evidence of a core of tropical water extending westward near $16^{\circ} \mathrm{S}$, the same latitude that Donguy and Hénin (1975b) find a strong westward current at both $163^{\circ} \mathrm{E}$ and $158^{\circ} \mathrm{E}$. The position is similar to that of the North Vanuatu Current, seen in the model, but is approximately one degree farther south.

Rochford (1959a,b) also shows some evidence for the North and South New Caledonia Currents, which show up in his salinity field. Scully-Power (1973) also finds a strong westward current extending down to $900 \mathrm{~m}$ along part of the North New Caledonia Current predicted by the model. At the surface Scully-Power finds the currents to be variable in direction, whereas the model shows primarily zonal flows (Fig. 3). Farther east, Tsuchiya (1982) shows a possible high salinity intrusion between Fiji and New Caledonia but the evidence is not very strong.

In these early surveys, the spacing between hydrographic stations was relatively large. For the present comparison it would be helpful if we could repeat the analysis using modern high-resolution CTD lines. North-south sections to the west of the islands of Fiji, Vanuatu, and New Caledonia would be particularly useful. Unfortunately few such sections exist. However there do exist French CTD sections along $165^{\circ} \mathrm{E}$ (NODC 1994) and data from the recent high quality WOCE P16 section along $180^{\circ} \mathrm{E}$ (WOCE 1998).

Figure 11 shows the temperature and salinity data from the French CTD section taken in June 1984 plotted using the same scales as Fig. 7. The observations reach $350 \mathrm{~m}$ and show the main near-surface features.

The largest differences between the model and observations occur in the mixed layer. The observed mixed layer is deeper and more variable than that of the model and it shows a large north-south temperature gradient. 
Temperature

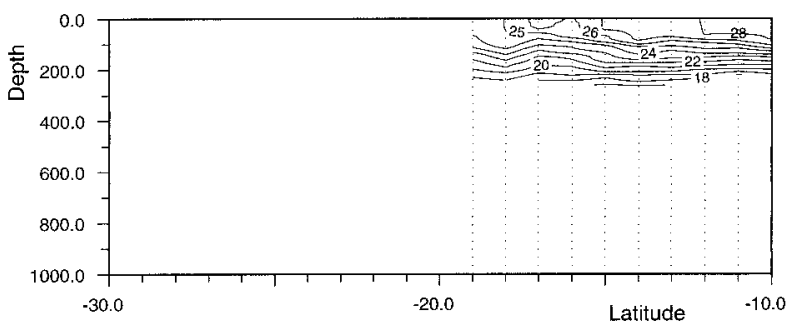

Salinity
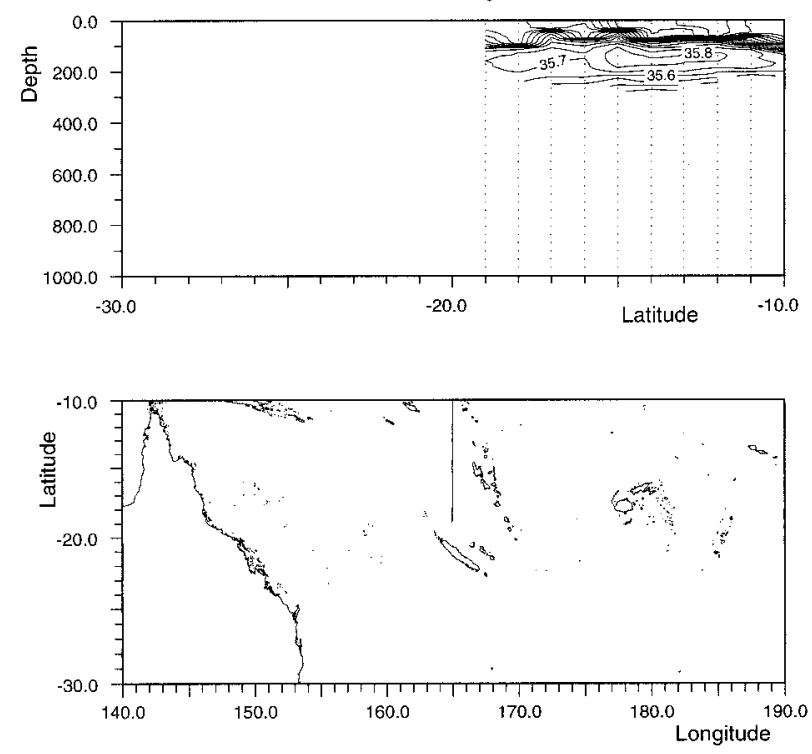

FIG. 11. CTD section from NODC Cruise 8344, taken by French scientists in Jun 1984. Dotted vertical lines correspond to the station positions.

Comparisons with individual model datasets and seasonal averages show similar discrepancies. The differences could be due to the smoothed surface fields used to force the model or to the model's lack of a full mixed layer scheme.

Below this, the model and observations are in better agreement. They both show high salinity cores near 200 $\mathrm{m}$ at $15^{\circ} \mathrm{S}$ and $18^{\circ} \mathrm{S}$ corresponding to the positions of the North and South Vanuatu Currents. The observations show the northern high salinity core extending to $12.5^{\circ} \mathrm{S}$. The extension is not seen in the model salinity field; however, the velocity field (see also Fig. 3) does show a possible secondary jet near $13.5^{\circ} \mathrm{S}$.

Figures 12 and 14 show the temperature, salinity, and cross-track geostrophic velocity fields from the WOCE P16 section. The stations south of Fiji were surveyed in September 1992, those to the north in August 1993. Figures 13 and 14 show the same data taken from the model averaged over the months of July, August, and September. Linear interpolation was used to transform the model temperature and salinity data to the P16 station positions. Potential temperature was converted to
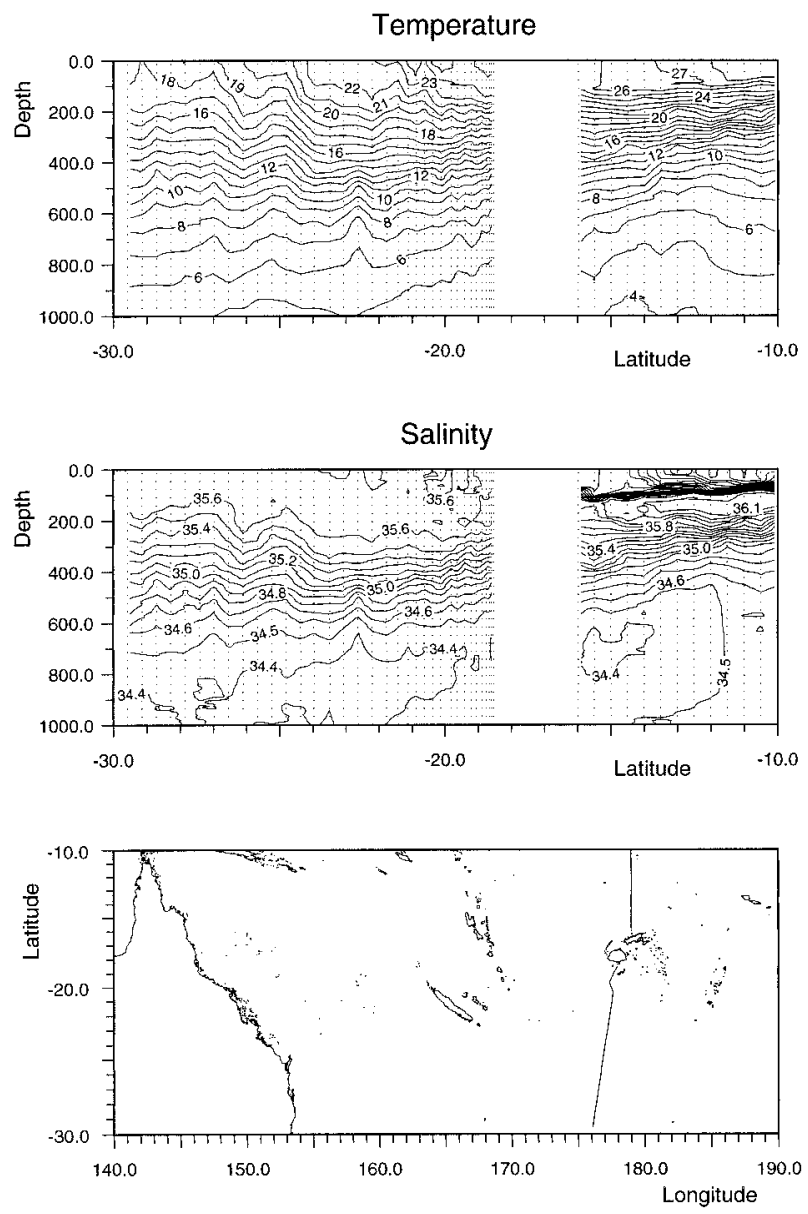

FIG. 12. CTD section (part) from WOCE Cruise P14. Dotted vertical lines correspond to the station positions.

in situ temperature, and the cross-track geostrophic velocities calculated in the same way as for the observed data, assuming, for each pair of stations, zero velocity at the deepest common level.

Along the P16 section, the observed mixed layer is again deeper and more variable than that shown in the model. Below the mixed layer north of Fiji, both the observations and the model show high salinity cores near $150 \mathrm{~m}$. However the observed values are higher, with a maximum of 36.1 psu compared with the model maximum of $35.7 \mathrm{psu}$. The observations also show the salinities reducing as Fiji is approached, whereas the model has its maximum values just north of the island.

South of Fiji, the observations show salinities of 35.6 psu extending down to $200 \mathrm{~m}$ and there is no evidence of the low salinity surface layer or the low salinity intrusion from the south seen in the model. However the model surface values are close to the values of Reid (1997). Thus, the high P16 surface salinities may reflect some seasonal or longer term variability in the region.

The agreement between model and observations improves at depth where they show broadly similar position and slope for the low salinity layer near $1000 \mathrm{~m}$. 

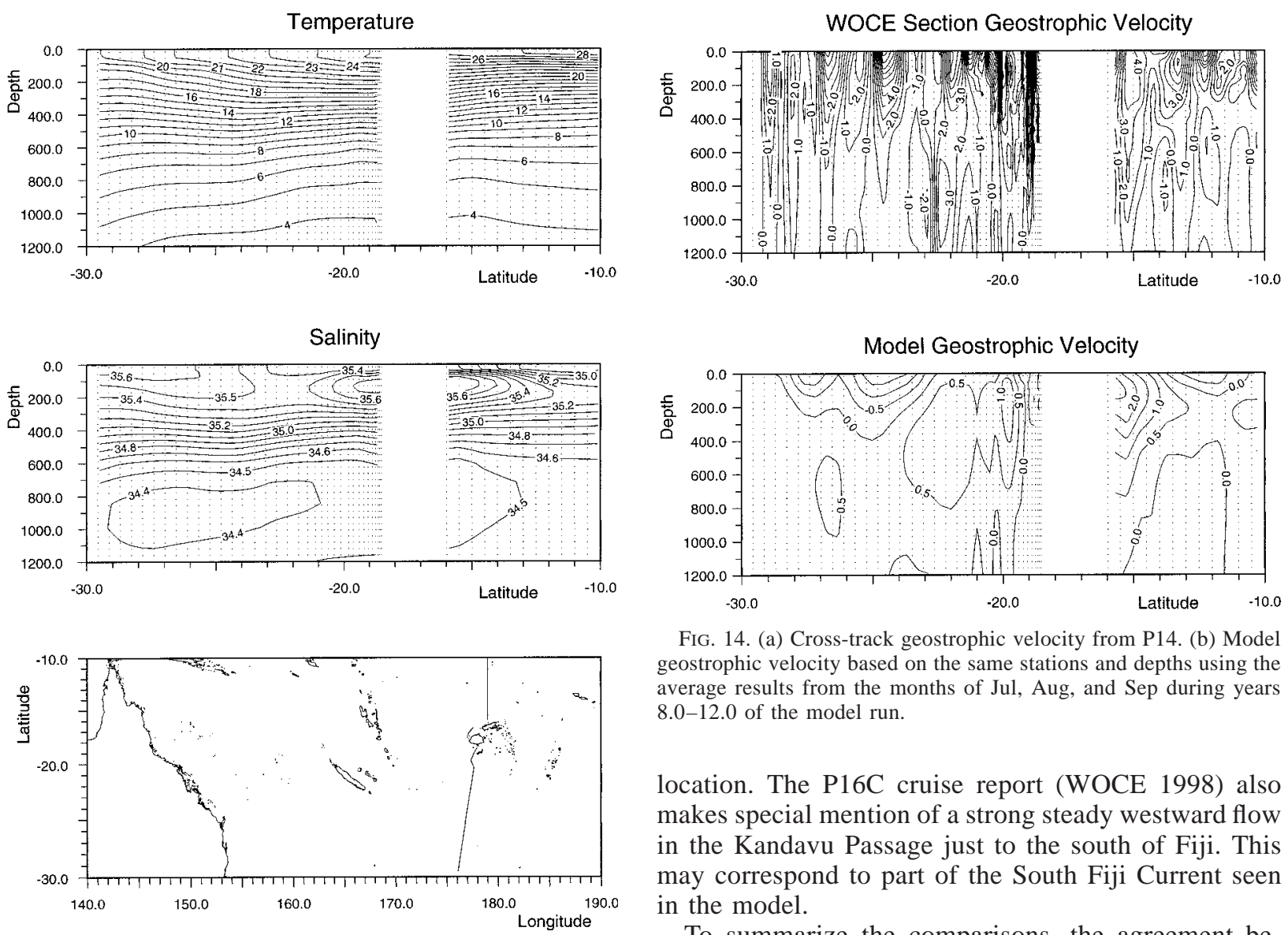

FIG. 13. Model average temperature and salinity along the P14 section. The average is for the months of Jul, Aug, and Sep during years $8.0-12.0$ of the model run. Dotted vertical lines correspond to the station positions on P14.

However there remain significant differences, for example, the observations show salinities of 34.4 psu extending north of Fiji to $14^{\circ} \mathrm{S}$, whereas in the model it only reaches $21^{\circ} \mathrm{S}$. The observations also show much more mesoscale noise.

The mesoscale signal also dominates the P16 geostrophic velocity field (Fig. 14). The model velocity field is much smoother and, at first sight, shows little agreement with the observations especially in the top $300 \mathrm{~m}$ where the observed variability is very large.

If we accept that the model has missed the source of the near-surface variability and that elsewhere it has a larger horizontal scale than the real ocean, then some agreement starts to emerge. Thus north of Fiji, both sections show a westward flowing current extending down to below $800 \mathrm{~m}$. Both also show a series of westward flowing currents to the south of Fiji and a region of mean eastward flow in the surface layers near $25^{\circ} \mathrm{S}$. The model shows a broad westward flow between 200 and $1000 \mathrm{~m}$ near $22.5^{\circ} \mathrm{S}$. The observations do not really support this, but they do show a strong narrow current with maxima near the surface and at $900 \mathrm{~m}$ in the same

FIG. 14. (a) Cross-track geostrophic velocity from P14. (b) Model geostrophic velocity based on the same stations and depths using the average results from the months of Jul, Aug, and Sep during years $8.0-12.0$ of the model run.

location. The P16C cruise report (WOCE 1998) also makes special mention of a strong steady westward flow in the Kandavu Passage just to the south of Fiji. This may correspond to part of the South Fiji Current seen in the model.

To summarize the comparisons, the agreement between the model and observations is not as good as one might have hoped. However there are indications from both the recent CTD sections and earlier surveys that the jet structures seen in the model do exist in reality.

\section{Discussion}

In the subtropics, the near-surface circulation of the ocean is driven primarily by the wind field and this is normally thought to produce large-scale gyres, which fill the ocean basin. In the South Pacific, the results from the OCCAM model highlight the fact that this largescale flow is blocked by a series of island arcs and other topographic features. The model shows that the result is a series of western boundary currents and zonal jets that dominate the flow in the region of the Coral Sea.

The present results confirm and extend those of Hughes (1993), who developed a one-degree model to study the Coral Sea region. Near $155^{\circ} \mathrm{E}$ the zonal velocity fields of the two models are in good agreement. Farther east the present model gives much more detail about the flow past Fiji and the other small-scale island groups and topographic features.

The overall picture coming from the model results is not unreasonable. However no model is perfect, so when interpreting the results one should make allowance for known deficiencies. Thus the mixed layer scheme used 
by the present model is very simple and results in mixed layers that are too shallow. In reality the mixed layer is often much deeper and as a result could erode the shallow high salinity cores, which are such a feature of the model results. This may explain why such cores are not apparent on the P16 section.

Other errors may result from the model's lack of horizontal resolution. Although the model resolution of $0.25^{\circ}$ is comparable with the first Rossby radius of the ocean in the subtropics, it is not small enough to correctly represent the finer-scale near-surface features seen in the hydrographic sections. The model resolution is also not fine enough to represent baroclinic instabilities that develop in the jets. In practice such instabilities may be widespread.

This may explain why the model's surface eddy kinetic energy is low when compared with values estimated from satellite altimeter measurements. If the jets are baroclinically unstable it may explain the enhanced kinetic energy seen in the satellite data along the line of the North New Caledonia Current described earlier.

Overall the comparisons between hydrographic observations and model results are slightly disappointing. The observations tend to support the existence of zonal jets but indicate that they have a much smaller horizontal scale than is shown in the model. For this reason I think that the next step is to encourage further experimental research on the currents of the region. Higher resolution models should also be run and I hope in time to report on such a study.

Acknowledgments. I wish to acknowledge the contributions of Mrs. B de Cuevas, Dr. A. Coward, Dr. C. Richmond, and Miss. E. Rourke in developing and running the OCCAM ocean model. I would also like to thank Dr. D. Roemmich, Dr. J. Bullister, Dr. G. Johnson, and their colleagues for the P14 data and the unknown French scientists for their CTD data.

\section{REFERENCES}

Andrews, J. C., and S. Clegg, 1989: Coral Sea circulation and transport deduced from modal information models. Deep-Sea Res. 36, 957-974.

Bryan, K., 1969: A numerical method for the study of the circulation of the world ocean. J. Comput. Phys., 4, 347-376.

Church, J. A., 1987: The East Australian Current adjacent to the Great Barrier Reef. Aust. J. Mar. Freshw. Res., 38, 671-683.

Cox, M. D., 1984: A primitive equation 3-dimensional model of the ocean. GFDL Ocean Group Tech. Rep. 1, Geophysical Fluid Dynamics Laboratory, 143 pp. [Available from GFDL/NOAA Princeton University, Princeton, NJ 08542.]

de Szoeke, R. A., 1987: On the wind driven circulation of the South Pacific Ocean. J. Phys. Oceanogr., 17, 613-630.

Delcroix, T., and C. Hénin, 1991: Seasonal and interannual variations of sea surface salinity in the tropical Pacific Ocean. J. Geophys. Res., 96 (C12), 22 135-22 150.

Doney, S. C., W. G. Large, and F. O. Bryan, 1998: Surface ocean fluxes and water-mass transformation rates in the coupled NCAR Climate Model. J. Climate, 11, 1420-1441.
Donguy, J. R., and C. Hénin, 1975a: Surface Waters in the North of the Coral Sea. Aust. J. Mar. Freshw. Res., 26, 293-296.

$\longrightarrow$, and $\longrightarrow$ 1975b: Evidence for the South Tropical Countercurrent in the Coral Sea. Aust. J. Mar. Freshw. Res., 26, 405409.

Hughes, R. D., 1993: An investigation of the Coral Sea with an ocean general circulation model. Ph.D. thesis, James Cook University of North Queensland, 190 pp. [Available from Department of Civil and Environmental Engineering, James Cook University, Townsville, Queensland 4811, Australia.]

Levitus, S., 1982: Climatological Atlas of the World Oceans. NOAA Prof. Paper No. 13, U.S. Govt. Printing Office, Washington, DC, $173 \mathrm{pp}$.

—_, 1994: World Ocean Atlas 1994. NOAA/NESDIS, Washington, DC, CD-ROM.

McClean, J. L., A. J. Semtner, and V. Zlotnicki, 1997: Comparisons of mesoscale variability in the Semtner-Chervin $14^{\circ}$ model, the Los Alamos Parallel Ocean Program 1/6 model and TOPEX/ Poseidon data. J. Geophys. Res., 102 (C11), 25 203-25 226.

Mesinger, F., and A. Arakawa, 1976: Numerical Methods Used in Atmospheric Models. GARP Publ. Ser. No. 17, World Meteorological Organization, $64 \mathrm{pp}$.

NERC, 1997: IOC/IHO general bathemetric chart of the oceans (GEBCO). British Oceanographic Data Centre, Bidston Observatory, Birkenhead, Merseyside, United Kingdom.

Pacanowski, R. C., and S. G. H. Philander, 1981: Parameterization of vertical mixing in numerical models of tropical oceans. $J$. Phys. Oceanogr., 11, 1443-1451.

Qiu, B., D. A. Koh, C. Lumpkin, and P. Flament, 1997: Existence and formation mechanism of the north Hawaiian Ridge Current. J. Phys. Oceanogr., 27, 431-444.

Reid, J. L., 1986: On the total geostrophic circulation of the South Pacific Ocean: Flow patterns, tracers and transports. Progress in Oceanography, Vol. 16, Pergamon, 1-61.

- 1997: On the total geostrophic circulation of the. Pacific Ocean: Flow patterns, tracers and transports. Progress in Oceanography, Vol. 39, Pergamon, 263-325.

Rochford, D. J., 1959a: The intermediate depth waters of the Tasman and Coral Seas. Part I: The 27.20 (sigma-t) surface. Aust. J. Mar. Freshw. Res., 11, 127-147.

_ 1959b: The intermediate depth waters of the Tasman and Coral seas. II: The 26.80 (sigma-t) surface. Aust. J. Mar. Freshw. Res., 11, 148-165.

Saunders, P. M., A. C. Coward, and B. A. de Cuevas, 1999: The circulation of the Pacific Ocean seen in a global ocean model Ocean Circulation and Climate Advanced Modelling project (OCCAM). J. Geophys. Res., 104 (C8), 18 281-18 299.

Scully-Power, P. D., 1973: Coral Sea flow budgets in winter. Aust. J. Mar. Freshw. Res., 24, 203-215.

Semtner, A. J., 1974: A general circulation model for the World Ocean. Tech. Rep. No. 9., Dept. of Meteorology, University of California, Los Angeles, 99 pp.

— global eddy-resolving model. J. Geophys. Res., 97 (C4), 54935550 .

Siefridt, L., and B. Barnier, 1993: Banque de Connées AVISO vent/ flux: Climatologie des analyses de surface du CEPMMT. Rep. 91-1430-025. [Available from AVISO, Météo-France, 42 Avenue Gustave Coriolis, 30157 Toulouse Cedex, France.]

Stammer, D., R. Tokmakian, A. Semtner, and C. Wunsch, 1996: How well does a $1 / 4$ global circulation model simulate large-scale oceanic observations? J. Geophys. Res., 101 (C11), 25 779-25 811.

Tsuchiya, M., 1981: The origin of the Pacific equatorial $13^{\circ} \mathrm{C}$ water. J. Phys. Oceanogr., 11, 794-812.

— 1982: On the Pacific upper-water circulation. J. Mar. Res., 40 (Suppl.), 777-799.

Thompson, S. R., 1995: Sills of the global ocean: A compilation. Ocean Modelling (Unpublished manuscripts), 109, 7-9.

Webb, D. J., 1993: A simple model of the effect of the Kerguelen 
Plateau on the strength of the Antarctic Circumpolar Current. Geophys. Astrophys. Fluid Dyn., 70, 57-84.

1995: The vertical advection of momentum in Bryan-CoxSemtner ocean general circulation models. J. Phys. Oceanogr., 25, 3186-3195.

, 1996: An ocean model for array processor computers. Comput. Geosci., 22, 569-578.

— B. A. de Cuevas, and A. C. Coward, 1998a: The first main run of the OCCAM global ocean model. Internal Report, Southampton Oceanography Centre, $44 \mathrm{pp}$. [Available from Southampton Oceanography Centre, Empress Dock, Southampton SO14 3ZH, United Kingdom.]
- and C. S. Richmond, 1998b: Improved advection schemes for ocean models. J. Atmos. Oceanic Technol., 15, 1171-1187. WOCE, 1998: WOCE global data Version 1.0. WOCE International Project Office, CD-ROM datasets. [Available from Southampton Oceanography Centre, Empress Dock, Southampton SO14 3ZH, United Kingdom.]

Wyrtki, K., 1962a: Geopotential topographies and associated circulations in the western South Pacific Ocean. Aust. J. Mar. Freshw. Res., 13, 89-105.

_ 1962b: The subsurface water masses in the western South Pacific. Aust. J. Mar. Freshw. Res., 13, 18-47.

- 1975: Fluctuations of the dynamic topography of the Pacific Ocean. J. Phys. Oceanogr., 5, 450-459. 